\title{
Characterisation and pathological variability of Exserohilum turcicum responsible for causing northern corn leaf blight (NCLB) disease in Malaysia
}

\author{
Abdulaziz Bashir Kutawa ${ }^{1,2}$, Kamaruzaman Sijam ${ }^{{ }^{*}}$, Khairulmazmi Ahmad ${ }^{1}$, Zulkifli Ahmad Seman ${ }^{3}$, Mohd $^{3}$ \\ Shahril Firdaus Ab Razak ${ }^{3}$ and Norzihan Abdullah ${ }^{3}$ \\ ${ }^{1}$ Department of Plant Protection, Faculty of Agriculture, University Putra Malaysia, 43400, Serdang, Selangor Darul \\ Ehsan, Malaysia. \\ ${ }^{2}$ Department of Biological Sciences, Federal University Dutsinma, Katsina State, Nigeria. \\ ${ }^{3}$ Centre for Marker Discovery and Validation (BT04), Biotechnology and Nanotechnology Research Centre, MARDI, \\ Persiaran MARDI-UPM, 43400 Serdang, Selangor.
}

Email: kama@upm.edu.my

Received 7 March 2016; Received in revised form 24 June 2016; Accepted 6 September 2016

\begin{abstract}
Aims: Corn is grown primarily for human consumption. It is considered as the second most important cereal crop after rice in Asia. Many diseases affect this crop due to planting of susceptible hybrids. This research is aimed to characterize the causative agent of northern corn leaf blight disease in Malaysia, caused by Exserohilum turcicum.

Methodology and results: Leaf samples were collected from infected farms of 2 corn growing areas of Peninsular Malaysia in 2015. A total of 5 fungal isolates were examined for cultural, morphological and molecular properties, and based on the results, the five isolates were identified as $E$. turcicum. The conidial shapes were observed to be elongated and spindle. Cultural characteristics showed that variation existed among the isolates in colony growth and colour. Mycelia growth rates of the isolates were significantly different on potato dextrose agar (PDA), corn meal agar (CMA) and potato sucrose agar (PSA) media, growth on CMA was faster than on PSA and PDA. The isolates were grouped into three groups based on colony colour i.e. light gray, gray and dark gray. The isolates were categorized into 2 groups based on growth namely, moderate growth and profused growth. The number of septa ranged from 5-7 to 7-10 representing isolates ET002 and ET003, respectively. Similarly, conidial length varied from $56.7 \mu \mathrm{m}$ to $89.44 \mu \mathrm{m}$ for isolates ET002 and ET003, respectively. The pathogenic variability tested on Thai Super Sweet (TSS) corn variety, showed that isolates ET001 and ET003 were more aggressive while isolate ET005 was less aggressive among the isolates tested.

Conclusion, significance and impact of the study: Both morphology and molecular results showed that, the isolates were identified as E. turcicum. The findings of this study will serve as a baseline for future studies and will help to minimize losses in yield.
\end{abstract}

Keywords: Exserohilum turcicum, corn, morphological, pathological, northern corn leaf blight

\section{INTRODUCTION}

Cereals are considered as the most vital staple crops in the world including Asia. These crops have the most established record of cultivation by humanity, and have taken after difficult and interrelated course of evolution (Harlan, 1995). Human civilisation has been firmly connected with cereals and has moved over the world conveying cereals culture amid humankind relocations. This is reflected through the journey of rice, wheat, millets and barley from old to the new world and of corn on the other hand. The three crops (wheat, rice and corn) represent over $90 \%$ of Asia's cereal production, with more than 284 million ha of prime Agricultural area (FAO, 2008). The minor crops include sorghum, barley and other several kinds of millets. Generally, production of cereals has been always expanding in Asia regardless of declining in cumulative region compared with 1980s (FAO, 2008).

Corn (Zea mays L.) belongs to Maydeae tribe from grass family, "Poaceae". It is marked as a main cereal crop of the world, because of absolute production (695 million tons) and per unit area yield of $4815 \mathrm{~kg} / \mathrm{ha}$ (FAO, 2008). Maize is of noteworthy significance in developing nations, where quickly expanding populace has officially out stripped the accessible nourishment supplies (Reddy et al., 2013). It is a standout amongst the most vital crops on the planet today. The cobs, grain, tassels, stalks, silk 
and leaves are of commercial value in many settings, however, that of grain is the most prominent (Akob and Ewete, 2010). It is an important monoecious and annual plant, which needs the assistance of man to spread its seeds for survival and propagation. Corn is the most productive plant for trapping the solar energy and changing it into food, it has an extraordinary pliancy adjusting to diverse distinctive states of sunlight, altitude, temperature, and humidity (OECD, 2003).

Plant diseases are considered as constraints throughout the world, and are across the board in grain crops in Asia and Malaysia in particular. There are many physiological processes by which plant diseases hinder yield and development (Boote et al., 1983). Grey spot, powdery mildew and northern corn leaf blight would continue to affect corn plant, if appropriate management strategies have not been employed. There are several pathogens that could infect a given cereal in the same crop cycle in the same area, thereby causing an injury profile (Serge Savary et al., 2006). Corn is associated with different types of diseases such as northern corn leaf blight, southern corn leaf blight (Cochliobolus heterostrophus), head smut (Sphacelotheca reiliana), corn smut (Ustilago maydis), downy mildew (Sclerophthora rayssiae, Sclerospora philippinensis), brown spot (Physoderma zeae-maydis) and rust (Puccinia sorghi).

Northern corn leaf blight (NCLB) (synonym, turcicum leaf blight) caused by Exserohilum turcicum (Pass.) Leonard and Suggs (1974), is an imperative foliar disease of corn around the world. In Malaysia, this disease have not been reported previously to cause significant yield loss in corn plant, however, the presence of this pathogen in areas of Pahang and Perak states have been confirmed in this study, and this will serve as a baseline for researches to work on in the future. NCLB is an endemic disease in cooler corn growing regions, and thought to be vital as far as its geographical distribution and potential to bring about loss in yield. NCLB can be serious in mid-elevation tropical zones where there is low temperature, cloudy weather and high humidity during the corn developing season (Singh, 2005). Losses in yield can be more than $50 \%$ if the symptoms show up before flowering (Raymundo and Hooker, 1981; Tefferi et al., 1996). However, the losses could be reduced if the disease occurs after flowering stage. The infection shows up as elliptical, long grey green or tan streaks. As the disease progresses, single lesions might collectively join to form vast blighted zones (Vieira et al., 2014). Losses of NCLB are more serious when the leaves over the ear are affected, or marginally at the post flowering stage. Warm and humid climate, late planting and past seasons corn deposits build the danger of infections (Blandino et al., 2012). NCLB is among the most imperative foliar diseases creating serious diminishment in grain and animal feed of around 16-98\% (Rajeshwar et al., 2014).

Exserohilum can be separated from different graminicolous helminthosporoid genera by a protruding hilum and truncate. The sexual morphology of Exserohilum has been set in Setosphaeria (Leonard and
Suggs, 1974). Differences in morphological characters of E. turcicum strains was investigated by Daniel and Narong (2006), and stated that the shapes of the conidia were bended, elongated and spindle. The average conidial length and width were found to be $93.97 \mu \mathrm{m}$ and $13.11 \mu \mathrm{m}$, respectively, while the number of septa was found to be ranged from 2-7. Harlapur et al. (2007) worked on cultural and morphological characters of $E$. turcicum strains, and different characters like spore germination, mycelial dry weight and colony diameter were observed. The use of DNA-based molecular tools and phylogenetic in species delineation has altered the classification of this fungal group, among others. Molecular analysis by using nuclear ribosomal DNA sequence of internal transcribed spacer (ITS) region, for instance have supplemented traditional method of classification, by providing an exact and faster method of species identification from distinctive host (Begoude et al., 2010; Mohali et al., 2010).

So far, different diseases have been reported in corn growing areas of Peninsular Malaysia. There is high requirement for an investigation on the portrayal of pathogen, and management strategies of NCLB disease in corn producing areas. Despite the fact that, many researchers have worked to find out the actual pathogen responsible for causing NCLB disease. But up to now, a lot of work needs to be done with regard to morphological variability of this pathogen, for better and easy identification and to put more emphasis on production of hybrids that are resistant to the disease. Based on this, the research work is focused to find out more about the morphological variability of the pathogen, in term of conidial shape, width, size, length and number of septa as well as to determine the aggressiveness of the fungal pathogen. The objective of this research is to characterise the causative agent of northern corn leaf blight disease and to study the pathological variability of the pathogen.

\section{MATERIALS AND METHODS}

\section{Sample collection and isolation of pathogens}

Two corn growing areas were used for collecting samples, and a total of 6-12 diseased samples were collected from farms in Titi Gantong, and Lembah Bertam of Perak and Pahang states, respectively, within Peninsular Malaysia in 2015. Field samples were labeled, kept in cold box and brought to the laboratory for studies.

\section{Isolation and identification of Exserohilum turcicum}

The isolation of fungus from diseased samples was carried out using method described by Manamgoda et al. (2012). Small portion of infected leaf tissue with some adjacent healthy tissues of around $0.5 \mathrm{~cm} \times 0.5 \mathrm{~cm}$ in diameter were cut. The leaf portions were surface sterilized in $70 \%$ ethanol for 1-3 min. The portions were removed with sterilized forceps and transferred into distilled water for 1-2 min. The portions were blotted on a sterilized filter paper in order to absorb moisture, and 
finally the portions were placed on suitable nutrient media (PDA) and the plates were completely sealed with Parafilm $\AA$, followed by incubation at $25^{\circ} \mathrm{C}$. Colonies were observed at 2-3 days interval until full growth was attained. Small portion of fungal mycelium from fully grown culture was aseptically transferred to a plate of fresh culture medium in order to obtain a pure culture of the E. turcicum.

\section{Cultural and morphological characterisation}

A 3-4 day old growing culture was used for this study. The growing culture in petri-plates were aseptically opened under laminar flow, a clean microscope glass slides were gently placed over the surface of the colonies touching the edge and the plates were resealed, followed by incubation under continuous light to produce spores. A total of five fungal isolates were studied for morphological and cultural characteristics after the culture reached 7-10 days. The colour and texture of the colony were also observed. Number of septa, conidial length, colour and width of 30 spores per each isolate were measured using eye piece micrometer and compound light microscope.

\section{Effect of media and pH on colony growth}

The effects of cultural conditions including $\mathrm{pH}$ and media were observed on colony growth of E. turcicum. Three different media namely, potato sucrose agar (PSA), potato dextrose agar (PDA) and corn meal agar (CMA) were used to determine the growth rate of each isolate grown at $26 \pm 1{ }^{\circ} \mathrm{C}$ incubation temperature for 2 weeks. Plugs of $0.5 \mathrm{~cm}$ in diameter (Da) containing mycelia from each of the five isolates were taken from actively growing edge of a culture (5 days old). The plugs were plated at the center of the three growing media mentioned, in order to study the growth rate, texture and appearance of the mycelium. Completely randomized design was used for this experiment, and colony growth of colonies were daily measured in two perpendicular directions (D1 and D2) without opening the plates, until the mycelium fully covered the plate. Three replicates were used for each isolate and for each medium. The difference in $\mathrm{pH}$ on $E$. turcicum growth was determined on PSA medium. Three $\mathrm{pHs}$ viz., 5, 7 and 9 were used for this study. Different $\mathrm{pH}$ was adjusted by adding required volume of $\mathrm{NaOH}$ and $\mathrm{HCl}$ solution. The media was autoclaved and poured in petri-plates. Each isolate was replicated three times and incubated at $26 \pm 1^{\circ} \mathrm{C}$. Colony growth of each isolate was measured at $3^{\text {rd }}, 5^{\text {th }}$ and $7^{\text {th }}$ day after incubation (DAI), respectively. The data was recorded and analysed to check for variation among the treatments statistically. Colony growth rate data ( $\mathrm{mm} /$ day) for each media and $\mathrm{pH}$ was subjected to one-way analysis of variances (ANOVA). Means at various treatments were separated using least significant difference (LSD) at $P \leq 0.05$ from SAS software (version 9.4), to compute the difference between the treatments.

\section{Pathological variability}

Susceptible variety Thai super sweet (TSS) of corn was used for this study. Seedlings were grown in plastic pots (30 cm in diameter) containing sterilised soil, a total of 30 pots were used for this study and three seeds of corn were sown in each of the pot, 25 pots containing seedlings were inoculated when the plants reached two weeks old, with the inoculum $\left(10^{4}\right.$ spores $\left./ \mathrm{ml}\right)$ of $E$. turcicum spore suspension, and the remaining five seedlings (control) were sprayed with sterilised distilled water. The pots were kept in a glasshouse to maintain the suitable temperature of $27-30{ }^{\circ} \mathrm{C}$ for incubation. The seedlings were inspected on daily basis to monitor the initiation of symptoms. The fungus was re-isolated from infected leaf parts on growing media (PSA) and subjected to pathogenicity test in order to confirm for Koch's postulates. Seedlings were assessed for external symptoms at one week interval, for a period of four weeks after inoculation (WAI). The external symptoms recorded were disease incidence (\%) and disease severity index (DSI), using rating scale adopted by Jenkins and Elliot (1946) based on a score of 0.5-5 disease classes. The pathogenicity of $E$. turcicum was quantified based on disease severity index (DSI). The pathological variability of each isolates were categorised based on five virulent scales, weak (DSI $=1-10 \%)$, mild $(11-20 \%)$, moderate $(21$ $30 \%)$, virulent $(31-50 \%)$ and highly virulent (> 50\%) (Shah et al., 2006).

\section{Molecular characterisation}

Molecular identification was carried using instructions of DNeasy Plant Mini Kit protocol to extract the DNA, followed by polymerase chain reaction (PCR) in order to amplify the DNA using universal primer (Kroon et al., 2004) TUBUF2 forward (5'-CGGTAACAACTGGGCCA AGG-3') and TUBUR1 reverse (5'- CCTGGTACTGCT GGTACTCAG-3'). PCR was conducted using a thermal cycler (VITAR SEGATEC-Bio Rad Company). The total volume for $\mathrm{PCR}$ reaction was $30 \mu \mathrm{L}$ reaction which contained $15 \mu \mathrm{L}$ PCR mastermix (Taq DNA polymerase, BIOMAX Company), $10 \mu \mathrm{L}$ of free nuclease water, $1.5 \mu \mathrm{L}$ of forward and reverse primer (TUBUF2 and TUBUR1), and $2 \mu \mathrm{L}$ of DNA template. Thermo cycling procedure was 4 minutes for initial denaturation $\left(95^{\circ} \mathrm{C}\right)$, followed by 30 cycles of denaturation $\left(95^{\circ} \mathrm{C}\right)$ for $30 \mathrm{sec}$, annealing at $56.6^{\circ} \mathrm{C}$ for $30 \mathrm{sec}, 1 \mathrm{~min}$ extension at $72^{\circ} \mathrm{C}$, and finally 5 min extension at $72{ }^{\circ} \mathrm{C}$. Gel electrophoresis and staining was done by taking $10 \mu \mathrm{l}$ of PCR product and $1 \%$ of agarose gel in TAE buffer solution (40 mM Tris, $20 \mathrm{mM}$ acetic acid and $1 \mathrm{mM}$ EDTA) at $80 \mathrm{~V}$ for $50 \mathrm{~min}$ at $25^{\circ} \mathrm{C}$. Flourosafe stain ( $1^{\text {st }}$ Base Company) was used to stain the gel, and the PCR products were viewed using UV light and photographed using gel documentation system (6.03, Syngene Laboratories). Molecular marker (DNA Ladder Mix, $1 \mathrm{~kb}, 1^{\text {st }}$ Base Company) was used to determine the size of the amplified DNA bands. Finally the PCR products were sent for sequencing. The $\beta$-tubulin 
sequences were aligned using BioEdit Software (version GenBank database (http://www.ncbi.nlm.nih.gov) with the help of BLASTN search (Altschul et al., 1997). The accession numbers for all the isolates were obtained from GenBank. A phylogenetic tree was constructed using MEGA6 software (version 4.0).

\section{RESULTS AND DISCUSSION}

\section{Cultural and morphological characterisation}

A total of five fungal isolates were obtained from infected leaf samples of corn. Results from morphological study showed that, the five isolates were identified as $E$. turcicum, most of the conidial shapes were spindle and elongated (Figure 1A). Moreover, the presence of protruding hilum at the extreme end of the conidia was noticed, which is the unique character of $E$. turcicum spore (Figure 1B), the colour of mycelia was brown and found to grow faster (Figure 2).

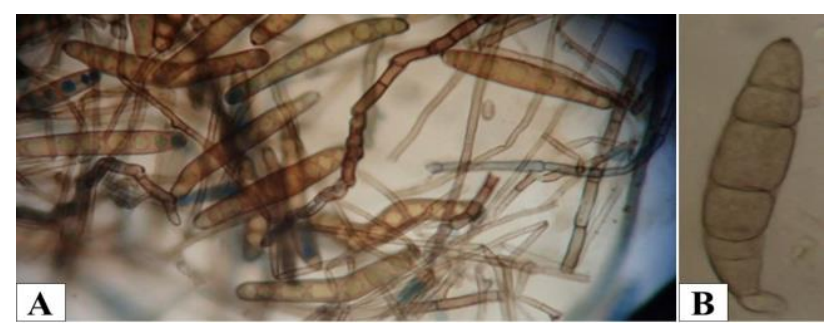

Figure 1: (A) Elongated and spindle shaped E. turcicum spores and (B) straight or elongated spore with a protruding hilum viewed under compound light microscope (magnification 40x).

Figure 2: Brownish mycelia of E. turcicum grown on PDA

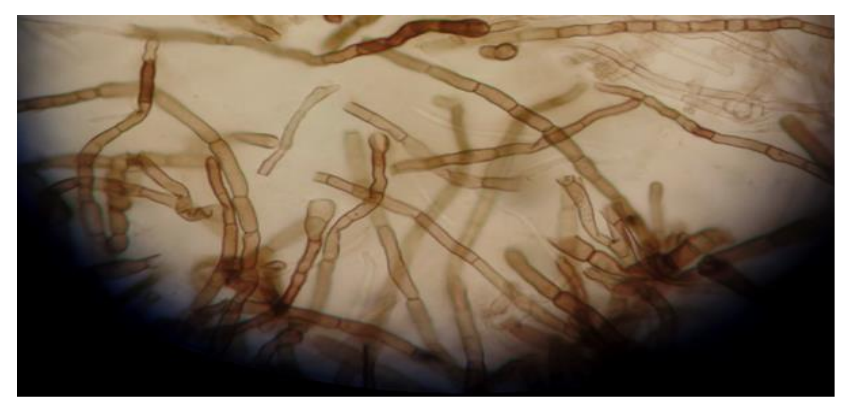

media for a period of two weeks of incubation viewed under compound light microscope (magnification 40x).

Based on spore production, isolate ET003 was found to produce more than the remaining isolates, while isolate ET004 was found to produce few spores compared to other isolates (Figure $3 \mathrm{~A}-\mathrm{E}$ ). This goes in line with the finding of Daniel and Narong (2006) who worked on cultural and morphological characteristics of E. turcicum. Cultural characterisation showed that variation in colony growth and colony colour existed among the five representative isolates. Based on colony colour, the isolates were grouped into three categories i.e. gray
7.2) and compared to the sequences in the (ET002 and ET004), dark gray (ET003 and ET005) and light gray (ET001) as indicated in Figure 4 A-E. In term of reversed colony appearance, the five isolates were grouped into three, dark grey (ET001, ET003 and ET005), light grey (ET002) and grey (ET004) as presented in Figure $5 \mathrm{~A}-\mathrm{E}$. Based on growth, the five isolates were categorised into two groups namely, moderate growth and profused growth (Table 1).

Table 1: Morphological characteristics of Exserohilum turcicum conidia for all the five isolates.

\begin{tabular}{|c|c|c|c|c|c|}
\hline \multirow[t]{2}{*}{$\begin{array}{l}\text { Isolate } \\
\text { Code }\end{array}$} & \multirow[t]{2}{*}{ Location } & \multirow{2}{*}{$\begin{array}{c}\text { Type of } \\
\text { Pathogen } \\
\text { Growth }\end{array}$} & \multicolumn{2}{|c|}{$\begin{array}{c}\text { Conidia } \\
\text { Measurement }\end{array}$} & \multirow[t]{2}{*}{$\begin{array}{l}\text { No of } \\
\text { septa }\end{array}$} \\
\hline & & & $\begin{array}{l}\text { Length } \\
(\mu \mathrm{m})\end{array}$ & $\begin{array}{l}\text { Width } \\
(\mu \mathrm{m})\end{array}$ & \\
\hline ET001 & $\begin{array}{l}\text { Titi } \\
\text { Gantong } \\
\text { (Perak) }\end{array}$ & $\begin{array}{l}\text { Profused } \\
\text { growth }\end{array}$ & 65.38 & 13.74 & $6-8$ \\
\hline ET002 & $\begin{array}{l}\text { Titi } \\
\text { Gantong } \\
\text { (Perak) }\end{array}$ & $\begin{array}{l}\text { Moderate } \\
\text { growth }\end{array}$ & 56.70 & 11.34 & $5-7$ \\
\hline ET003 & $\begin{array}{l}\text { Titi } \\
\text { Gantong } \\
\text { (Perak) }\end{array}$ & $\begin{array}{l}\text { Profused } \\
\text { growth }\end{array}$ & 89.44 & 13.28 & $7-10$ \\
\hline ET004 & $\begin{array}{l}\text { Lembah } \\
\text { Bertam } \\
\text { (Pahang) }\end{array}$ & $\begin{array}{l}\text { Moderate } \\
\text { growth }\end{array}$ & 78.42 & 12.63 & $6-9$ \\
\hline ET005 & $\begin{array}{l}\text { Lembah } \\
\text { Bertam } \\
\text { (Pahang) }\end{array}$ & $\begin{array}{l}\text { Moderate } \\
\text { growth }\end{array}$ & 66.24 & 13.56 & $6-8$ \\
\hline
\end{tabular}

The number of septa in all the five isolates ranged from 5-7 to 7-10 representing isolates ET002 and ET003, respectively. Similarly, the conidial length varied from $56.7 \mu \mathrm{m}$ to $89.44 \mu \mathrm{m}$ for isolates ET002 and ET003, respectively. Likewise conidial width varied from $11.34 \mu \mathrm{m}$ to $13.74 \mu \mathrm{m}$ for isolates ET002 and ET001, respectively. These findings go in line with the work of Sivanesan (1987), Harlapur et al. (2007) and Rajeshwar et al. (2014). In addition, Harlapur et al. (2007) investigated the growth of sixteen isolates and reported that growth in five isolates was considered as fast and profuse growing. Poor and moderate growth was observed in three isolates. Minimum and maximum colony growth was seen following twelve days of incubation.

\section{Effect of media and pH on colony growth}

Conidial growth rates of the five isolates on PDA, CMA and PSA were significantly different, with CMA showing the highest growth rate $(11.96 \mathrm{~mm} /$ day $)$ with mycelia completely covering the Petri-plate within 6-7 days. This was followed by PSA $(9.10 \mathrm{~mm} /$ day $)$ and covering the plate within 8-9 days and PDA media $(7.64 \mathrm{~mm} /$ day) covering the plate within 9-12 days as indicated in Table 2. Based on this finding, it can be suggested that CMA is the best media to be used for culturing E. turcicum in the laboratory.

All the five isolates were grown at different range of $\mathrm{pH}$ starting from 5, 7 and 9. However, $\mathrm{pH} 7$ was found to 


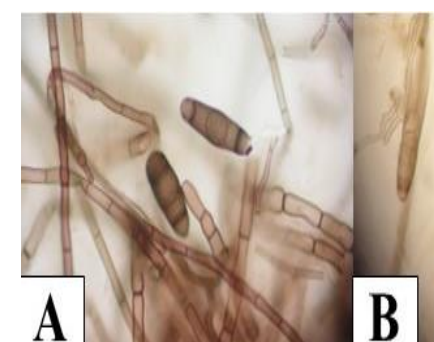

Figure 3: Spores produced by five isolates ET001 (A), ET002 (B), ET003 turcicum viewed under compound light microscope (magnification 40x).

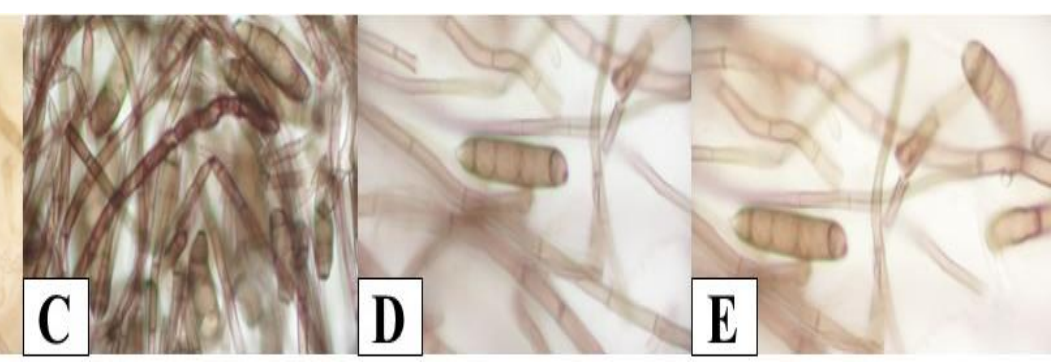

(C), ET004 (D) and ET005 (E) of E.
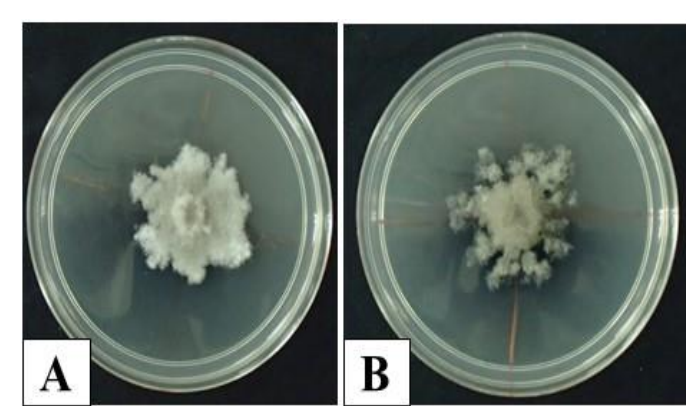
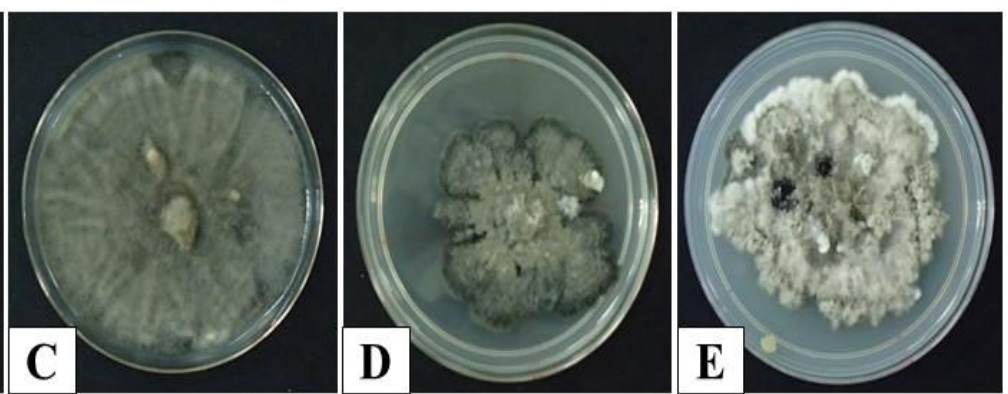

Figure 4: Exserohilum turcicum culture of five isolates showing grey colour (A and B), dark grey colour (C and D) and light grey colour (E) grown on PDA for a period of two weeks of incubation.

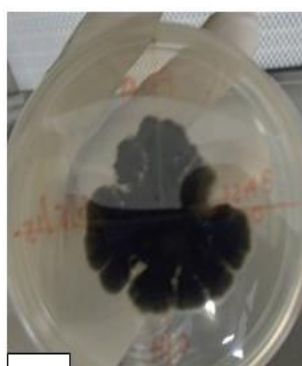

A

\section{B}

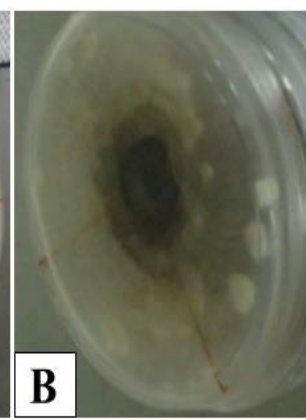

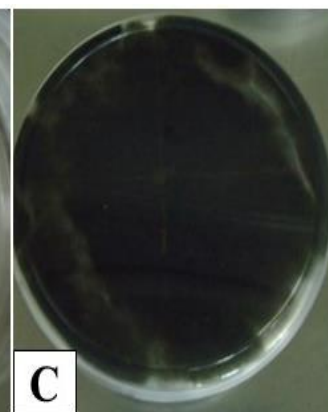

D
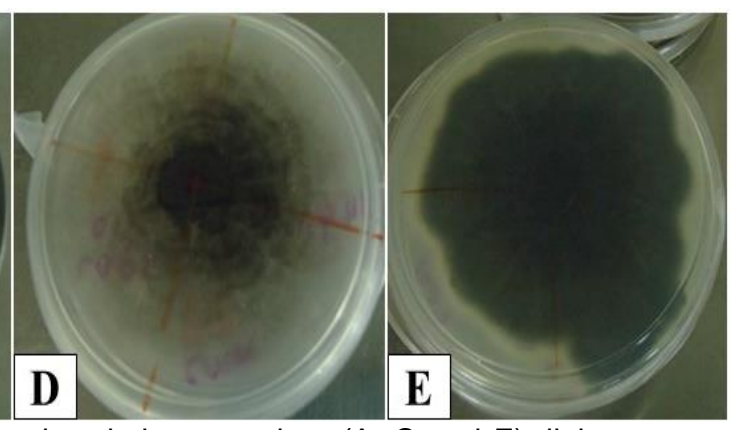

Figure 5: Reversed view of E. turcicum culture of five isolates showing dark grey colour (A, C and E), light grey colour (B) and grey clour (D) grown on PDA media for a period of two weeks of incubation.

Table 2: Effect of media on colony growth of E. turcicum isolates for a period of two weeks after incubation.

\begin{tabular}{llll}
\hline Isolate & PSA (mm/day) & PDA (mm/day) & CMA (mm/day) \\
\hline ET001 & $7.9 \mathrm{ab}$ & $3.7 \mathrm{c}$ & $8.6 \mathrm{a}$ \\
ET002 & $8.3 \mathrm{~b}$ & $7.7 \mathrm{~b}$ & $12.8 \mathrm{a}$ \\
ET003 & $8.6 \mathrm{ab}$ & $7.0 \mathrm{~b}$ & $12.8 \mathrm{a}$ \\
ET004 & $12.8 \mathrm{a}$ & $12.8 \mathrm{a}$ & $12.8 \mathrm{a}$ \\
ET005 & $7.9 \mathrm{~b}$ & $7.0 \mathrm{~b}$ & $12.8 \mathrm{a}$ \\
\hline Mean & $9.10 \mathrm{ab}$ & $7.64 \mathrm{~b}$ & $11.96 \mathrm{a}$ \\
\hline Number of days to & $8-9$ days & $9-12$ days & $6-7$ days
\end{tabular}

cover the plate

Means within rows followed by the same letter are not significantly different at $\mathrm{P} \leq 0.05$. 
be the best for growing $E$. turcicum with $4.72 \mathrm{~mm} /$ day, $6.36 \mathrm{~mm} /$ day and $6.96 \mathrm{~mm} /$ day at the $3^{\text {rd }}, 5^{\text {th }}$ and $7^{\text {th }}$ day after incubation, respectively. And this was followed by $\mathrm{pH} 9$ with $4.84 \mathrm{~mm} /$ day, $6.14 \mathrm{~mm} /$ day and $6.94 \mathrm{~mm} /$ day at the same incubation periods. $\mathrm{pH} 5$ showed the least growth at one week after incubation by having 3.58 $\mathrm{mm} /$ day, $5.0 \mathrm{~mm} /$ day and $6.02 \mathrm{~mm} /$ day at $3^{\text {rd }}, 5^{\text {th }}$ and $7^{\text {th }}$ day, respectively (Figure 6). Didvania et al. (2012) reported that, a slightly acidic $\mathrm{pH}$ of 6.5 in PDA medium was suitable for reproduction and pathogen growth of Drechslera bicolor (genus Helminthosporium).

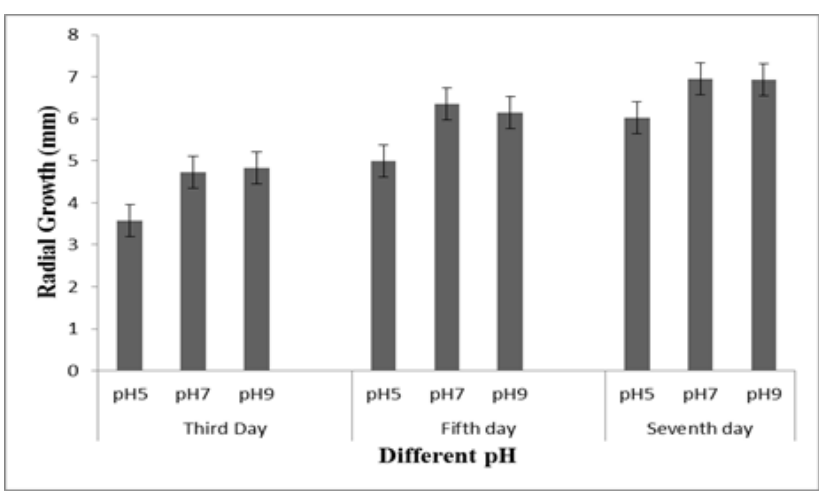

Figure 6: Effect of $\mathrm{pH}$ on colony growth of E. turcicum for a period of one week after incubation.

Misra and Singh (1963) examined the impact of temperature and moistness on the growth of corn isolate of $E$. turcicum and found that, the ideal temperatures for spore development, germination in culture, and for infection of NCLB disease were $30^{\circ} \mathrm{C}, 20-30{ }^{\circ} \mathrm{C}$ and 25 $30^{\circ} \mathrm{C}$, respectively. Bergquist and Masias (1974) reported that the ideal growing temperature of fungal isolates obtained from corn and sorghum was $28^{\circ} \mathrm{C}$, while bounteous sporulation was seen at $24^{\circ} \mathrm{C}$. Isolates from various agro-environmental areas showed differences in pigmentation, morphology, sporulation and growth rate in various kinds of media Muiru et al. (2008). The diverse light regimes had huge impact on the rate at which $E$. turcicum grow and sporulate. Different types of media and temperatures of incubation significantly affected the growth rate of various isolates. The ideal temperature was $25^{\circ} \mathrm{C}$ and only one isolate had a negligible growth at less than $10^{\circ} \mathrm{C}$, and no growth was seen in all the isolates at $40{ }^{\circ} \mathrm{C}$ (Muiru et al., 2008).

\section{Pathological variability}

The pathological variability of all the isolates was assessed on susceptible corn variety to NCLB disease. Data of inoculated seedlings were recorded at the time when the light spots of the disease symptoms appeared in the first day on leaves of the tested seedlings (14 days old) as presented in Figure 7A. The symptom of NCLB disease first appeared as an elliptical long, gray or tan streak on the surface of the leaves, as the lesion matured, the symptoms progresses to form single, long lesions measuring $(3-12 \mathrm{~cm})$ long of blighted zones, these lesions

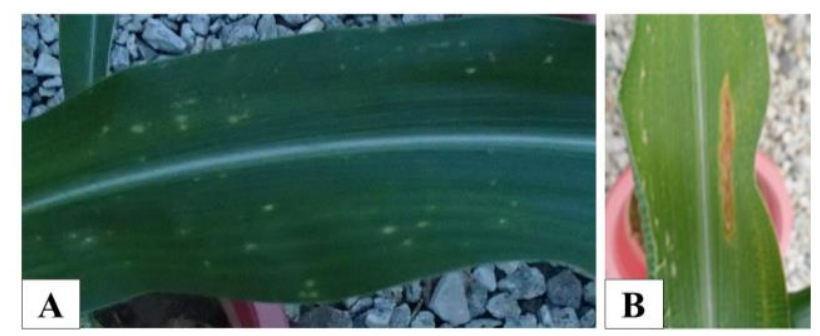

Figure 7: (A) The symptom first appeared as elliptical grey streaks on the surface of the leaves, (B) Over time, the symptoms progresses to form single, long and cigar shaped lesions or blighted zones.

are cigar-shaped and formed blighted portions, the lesions produced are unique and helped to confirmed the presence of $E$. turcicum pathogen (Figure 7B). Disease severity index (DSI) was calculated based on the pathogenic variability as indicated in Table 3 . The findings of this study showed that, ET001 and ET003 showed the highest level of aggressiveness with $48 \%$ each, while isolate ET005 was found to be the least aggressive among the isolates been examined by having $22 \%$. For the control, there were none of the seedlings that showed any symptom during the study. Based on this study isolates ET001, ET002, ET003 and ET004 were classified to be virulent isolates, while ET005 was found to be moderate isolate. The findings of this study will help plant pathologist to understand the aggressive variability of the pathogen, as well as to understand more about the conditions that are favourable for the disease to occur. This will also help them to develop some measures like resistant cultivars and the use of chemicals in managing NCLB disease, which can help the farmers to increase their income.

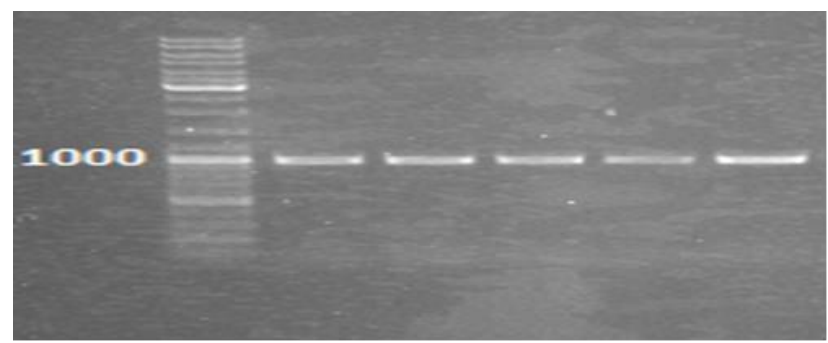

Figure 8: Representative bands of PCR product from $\beta$ tubulin gene. Amplification fragments size of 1000 base pairs (bp).

Levy and Pataky (1992) demonstrated that strains from various geographical regions were distinctive in parasitic action while strains of the same area indicated less variability. Muiru et al. (2010) stated that, E. turcicum isolates showed differences in virulence level and in isolates B3, B5 and G7, the lesions combine to form huge chlorotic and necrotic lesions, while in isolates Sorte 2, S62 and G5, the lesions remained as little chlorotic specks limited in the regions secured by the drop of the spore suspension. The period of incubation extended 
Table 3: Disease severity index (\%) and categories of E. turcicum isolates from infected corn plants tested on TSS corn seedlings

\begin{tabular}{llllll}
\hline Isolate & 1WAI & 2WAI & 3 WAI & 4 WAI & $\begin{array}{l}\text { Pathogen } \\
\text { categorized }^{*}\end{array}$ \\
\hline ET001 & $32 \%$ & $36 \%$ & $44 \%$ & $48 \%$ & Virulent \\
ET002 & $28 \%$ & $44 \%$ & $44 \%$ & $44 \%$ & Virulent \\
ET003 & $28 \%$ & $32 \%$ & $48 \%$ & $48 \%$ & Virulent \\
ET004 & $26 \%$ & $28 \%$ & $28 \%$ & $32 \%$ & Virulent \\
ET005 & $10 \%$ & $16 \%$ & $22 \%$ & $22 \%$ & Moderate \\
\hline
\end{tabular}

${ }^{*}$ The pathogen was categorized based on DSI (\%) at fourth week after inoculation.

from two to six days for the most aggressive and the least aggressive strains respectively, and the normal period of incubation was 3.8 days for most of the isolates (Muiru et al., 2010). Robert and Sprague (1960) assessed the response of eight in bred lines of corn, to twenty-seven single-conidial strains of $E$. turcicum by rating disease on a scale from one to 11 , the response of 27 strains to corn ranged from $1.1 \mathrm{~cm}^{2}$ to $7.1 \mathrm{~cm}^{2}$, along these lines showing an extensive variability of aggressiveness. Slight variability in virulence level among isolates from the inbred lines $\mathrm{Cl} .64$ and K64 indicated that, there are some physiological specializations among isolates for the halfway resistance of $\mathrm{C} .164$ and $\mathrm{K} 64$, in relation to differences among isolates in term of aggressiveness (Robert and Sprague, 1960). Nelson et al. (1970) stated that size of lesions on a susceptible line, R4, ranged from 1.5 to $11.5 \mathrm{~cm}^{2}$ for 69 diverse isolates of E. turicum. The quantity of lesions on the in bred line C128A, was marginally corresponded with the size of the lesion, demonstrating that aggressive level of isolates is expressed through different parts of the infection cycle. Similar to Robert and Sprague (1960), Nelson et al. (1970) found the relationship between physiological specialization and aggressiveness of $E$. turcicum pathogen.

\section{Molecular Characterisation}

Results from molecular identification indicated that, five of the isolates were identified as Setosphaeria turcica, telemorph (synonym E. turcicum, anamorph). Representative bands of PCR products were viewed using gel documentation system (Figure 8). $\beta$-tubulin gene sequences analysis made it possible to verify the identity of fungal strains. However, up to now there are limited numbers of $\beta$-tubulin rDNA sequences in the public databases. In this study, it was therefore not possible to resolve the taxonomic affiliation. Figure 9 represent the phylogenetic relationship of all the five isolates, all the isolates were clustered in the same clade (clade 1), while other species of Bipolaris zeicola, $B$. maydis, Cochliobolus heterostrophus, were all clustered in the second clade (clade 2). In this study, Alternaria infectoria served as an out group by fallen in neither of the 2 clades. B-tubulin gene sequences helped us to investigate and analyses the phylogenetic affiliation of $E$. turcicum and other species of fungi that are closely related. $\beta$-tubulin gene sequences of ET001 (947), ET002 (946), ET003 (958), ET004 (949) and ET005 (946) showed high level of similarity (97\%) identity with reference isolate from genbank (accession number XM_008032318). The respective accession numbers obtained for the five isolates of $E$. turcicum were KU670340 (ET001), KU670341 (ET002), KU670342 (ET003), KU670343 (ET004) and KU670344 (ET005), respectively.
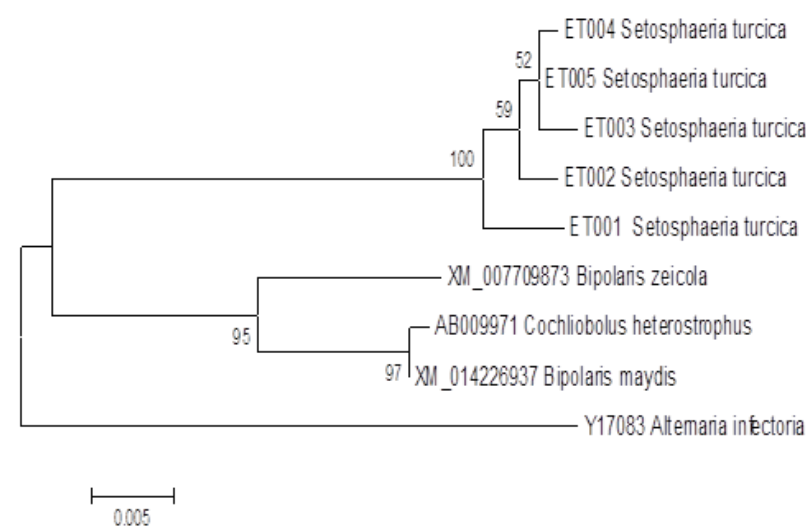

Figure 9: Phylogenetic relationship of E. turcicum isolates compared with accession numbers of other species. Phylogenetic tree inferred by maximum likelihood analysis based on rDNA sequences. Numbers below the branches represent the percentage for each branch in 1000 bootstrap replications.

\section{CONCLUSION}

At the end of this study, the variability of E. turcicum pathogen responsible for causing NCLB disease in Malaysia was studied, the pathogen was identified as $E$. turcicum using both morphological and molecular methods. CMA and PSA media were the most suitable nutrient media, for supporting the growth of the pathogen, E. turcicum was found to be capable of growing in a wide range of locations either at low or high land. Moreover, the aggressiveness of the five isolates was categorised into two main groups i.e. virulent and moderate. 
Therefore, this study will help plant pathologist in future to understand more about the variability of the pathogen, and how to come up with management strategies which can reduce the incidence of the disease, in order to minimize loss in yield. The study will also serve as the baseline for in-vitro and in-vivo researches of NCLB disease of corn in the future.

\section{ACKNOWLEDGEMENT}

The authors are grateful for the financial support provided by the Malaysian Government through its Malaysian Agricultural Research and Development Institute (MARDI), and Green World Genetics (GWG).

\section{REFERENCES}

Akob, C. A. and Ewete, F. K. (2010). Effect of four MidAltitude maize varieties on oviposition, development and sex ratio of Sitophilus zeamais (Motschulsky) (Coleoptera: Curculionidae). African Entomology 18, 253-258. DOl.org/10.4001/003.018.0202.

Altschul, S. F., Madden, T. L., Schaffer, A. A., Zhang, J., Zhang, Z., Miller, W. and Lipman, D. J. (1997). Blast and Psi-Blast: Protein database search programs. Nucleic Acid Research 25, 3389-3402. DOI:10.1093/nar/25.17.3389.

Begoude, B. A. D., Slippers, B., Wingfield, M. J. and Roux, J. (2010). Botryosphaeriaceae associated with Terminalia catappa in Cameroon, South Africa and Madagascar. Journal of Mycological Progress 9, 101123. DOI: http://dx.doi.org/10.7872/crym.v35.iss 1 . 2014.63.

Bergquist R. R. and Masias, O. R. (1974). Physiologic specialization in Trichometasphaeria turcicaf sp. and T. turcica f. sp. sorghi in Hawaii. Phytopathology 64, 645-649.

Blandino, M., Galeazzi, M., Savoia, W. and Reyneri, A. (2012). Timing of azoxystrobin+propiconazole application on maize to control northern corn leaf blight and maximize grain yield. Journal of Field Crops Research 139, 20-29. DOI: 10.1016/j.fcr.2012.09.014.

Boote, K. J., Jones, J. W., Mishoe, J. W. and Berger, R. D. (1983). Coupling pests to growth simulators to predict yield reductions. Phytopathology 73, 15811587.

Daniel A. and Narong, S. (2006). Morphological, cultural and pathogenicity variation of Exserohilum turcicum (Pass) Leonard and Suggs isolates in maize (Zea mays L.). Journal of Natural Science 40, 341-352.

Didvania, S., Shah, R. and John, K. S. (2012). A new disease of bell pepper (Capsicum annuum var.grossum) caused by Drechslera bicolor, its pathophysiology, efficacy of fungicides and botanicals. Plant Pathology Journal. 11, 68-72. DOI: 10.3923/ppj. 2012.68.72.

Food and Agricultural Organization (FAO). (2008). Statistical database.http://www.fao.org (Verified on 4 September 2008).
Harlan, J. R. (1995). The Living Fields: Our Agricultural Heritage. Cambridge University Press. London. pp. 239-240.

Harlapur, S. I., Kulkarni, M. S., Hedge, Y. and Kaikarni, S. (2007). Variability in Exserohilum turcicum (Pass) leonard Suggs, causal agent of turcicum leaf blight of maize. Karnatakar Journal of Agricultural Research 20, 665-666.

Jenkins, M. T. and Elliot, C. (1946). Heliminthosporium turcicum leaf blight of corn. Phytopathology 36, 660666.

Kroon, L. P., Bakker, F. T., Van den Bosch, G. B., Bonants, P. J. and Flier, W. G. (2004). Phylogenetic analysis of Phytophthora species based on mitochondrial and nuclear DNA sequences. Fungal Genetics and Biology 41, 766-782.

Leonard, K. J. and Suggs, E. G. (1974). Setosphaeria prolata, the ascigerous state of Exserohilum prolatum. Mycologia 66, 281-297. DOI:10.2307/3758363.

Levy, Y. and Pataky, J. K. (1992). Epidemiology of northern leaf blight on sweet corn. Phytoparasitica 20, 53-66. DOI:10.1007/BF02995636.

Manamgoda, D. S., Cai, L. and McKenzie, E. H. C. (2012). A phylogenetic and taxonomic re-evaluation of the Bipolaris - Cochliobolus - Curvularia complex. Fungal Diversity 56, 131-144. DOI:10.1007/s13225. 012.0189-2.

Misra A. P. and Singh S. P. (1963). Effect of temperature and humidity on the development of Helminthosporium turcicum Pass. Indian Phytopathology 16, 301-306.

Mohali, S., Slippers, B. and Wingfield, M. J. (2010). Two new Fusicoccum species from Acacia and Eucalyptus in Venezuela based on morphology and DNA sequence data. Journal of Mycological Research 110, 405-413. DOI:10.1016/j.mycres.2006.01.006.

Muiru W. M, Mutitu, E. W. and Ken, J. W. (2008). Distribution of turcicum leaf blight of maize in Kenya and cultural variability of its causal agent, Exserohilum turcicum. Journal of Tropical Microbiology and Biochemistryy 4, 32-39.

Muiru W. M., Koopmann, B., Tiedemann, A. V. and Mutitu, K. J. (2010). Race typing and evaluation of aggressiveness of Exserohilum turcicum isolates of Kenyan, German and Austrian Origin. World Journal of Agricultural Sciences 6, 277-284.

Nelson R. R., Robert, M. D. and schiefele G. L. (1970). Interaction of genes for phyto-pathogenicity and virulence in Trichometaspaeria turcica with different numbers of gene for vertical resistance in Zea mays. Phytopathology 60, 1250-1254.

Organization for Economic Development and Cooperation (OECD). (2003). OECD's World Wide Web site http://www.oecd.org/ehs/ [Verified on 23 July 2003].

Rajeshwar, R. P., Narayan, R., Ranga, P. and Sokka, S. R. (2014). Cultural and morphological variability among Exserohilum turcicum isolates. International Journal of Scientific and Research Publication 3, 5459. 
Raymundo, A. D. and Hooker, A. L. (1981). Measuring the relationship between northern corn leaf blight and yield losses. Plant Disease 65, 325-327. DOI: 10.1094/PD-65-325.

Reddy, T. R., Reddy, P. N. and Pradesh, A. (2013). Turcicum leaf blight of maize incited by Exserohilum turcicum: A review. International Journal of Applied Biology and Pharmaceutical Technology 5, 54-59.

Robert A. L. and Sprague G. F. (1960). Adaption of the corn leaf blight fungus to a resistant and susceptible corn host. Phytopathology 50, 261-263.

Serge Savary, S., Teng, P. S., Willocquet, L. and Nutter, F. W. (2006). Quantification and modeling of crop losses: A review of purposes. Phytopathology 44, 89-112. DOI: 10.1146/ annurev.phyto.44. 070505.143342.

Shah, S. S., Rahman, H., Khalil, I. H. and Rafi. A. (2006). Reaction of two maize synthetics to maydis leaf blight following recurrent selection for grain yield. Journal of Agriculture 22, 263-269.

Singh, N. P. (2005). Maize in India: Production systems, constraints, and research priorities. Indian Research Journal of Extension Education 42, 821-833.

Sivanesan, A. (1987). Graminicolous species of Bipolaris, Curvularia, Drechslera, Exserohilum and their teleomorphs. Mycological Papers 15, 1-261.

Tefferi, A., Mengestu, H. and Welz, H. G. (1996). Assessment of damage and grain yield loss in maize caused by northern leaf blight in western Ethopia. Journal of Plant Disease and Protection 103, 353-363.

Vieira, R. A., Mesquini, R. M., Silva, C. N., Hata, F. T., Tessmann, D. J. and Scapim, C. A. (2014). A new diagrammatic scale for the assessment of northern corn leaf blight. Journal of Crop Protection 56, 55-57. DOI:10.1016/j.cropro.2011.04.018. 